\title{
Murine Responses to Immunization with Pertussis Toxin and Bovine Serum Albumin: I. Mortality Observed after Bovine Albumin Challenge is Due To an Anaphylactic Reaction
}

\author{
SUSAN E. WIEDMEIER, HUN-TAEG CHUNG, BAIK HWAN CHO, UH-HYUN KIM, AND \\ RAYMOND A. DAYNES
}

Department of Pathology, University of Utah Medical Center, Salt Lake City, Utah 84132

\begin{abstract}
It has been suggested that pertussis toxin (Ptx) is involved in the pathogenesis of the adverse neurologic reactions that can occur in infants and children after pertussis immunization. One group of investigators has recently reported that a clinical syndrome with pathological features very similar to post-pertussis vaccination encephalopathy can be induced in specific strains of mice after their immunization with bovine serum albumin (BSA) and Ptx. The aim of this investigation was to further characterize the immunologic mechanisms operative in this murine model. Studies were undertaken to determine whether the role played by $\mathrm{Ptx}$ in this condition required the A-protomer of the toxin to enter a cell and ADPribosylate a nucleotide binding protein (a Class I activity) or was dependent upon the binding of the B-oligomer of the toxin to the surface of target cells (a Class II activity). The results of our experiments have established that the disease induced by coimmunizing mice with Ptx and BSA is due to an immediate type hypersensitivity reaction rather than an encephalopathy and that the mechanism of action of Ptx in this system seems to be dependent upon a Class II activity of the toxin and independent of its ADP-ribosyl transferase activity. (Pediatr Res 22: 262-267, 1987)
\end{abstract}

Abbreviations

Ptx, pertussis toxin

$\mathrm{Ni}$, subunit of the guanine nucleotide regulatory protein BSA, bovine serum albumin

mPtx, methylated pertussis toxin

$I V$, intravenous

IP, intraperitoneal

${ }^{3}[$ H]NAD, Tritiated nicotinamide adenine dinucleotide

IAP, islet-activating protein

LPF, lymphocytosis-promoting factor

HSF, histamine-sensitizing factor

MEM, minimal essential medium

FCS, fetal calf serum

Convulsions, infantile spasms, hypotonic hypotensive episodes, encephalopathy, and even death have been reported following pertussis vaccination in young children $(1-8)$. It has been suggested but not proven that at least a portion of these sequelae

Received October 6, 1986; accepted March 27, 1987.

Correspondence and requests for reprints Raymond A. Daynes, Ph.D., Department of Pathology, University of Utah Medical Center, Salt Lake City, UT 84132

Supported in part by N1H Grants CA33065, CA25917, and CA22126. may be caused by the Ptx contained within vaccine preparations $(9,10)$. Ptx, also referred to as IAP, LPF, or HSF is one of the exotoxins produced by Bordetella pertussis. It is an oligomeric protein $(\mathrm{Mr}=117,000)$ consisting of an $\mathrm{A}$ (active) protomer and a $\mathrm{B}$ (binding) oligomer (11) and is known to have a wide variety of biological activities (12). The diversity of these activities in vivo is related to the multiplicity of target cells that are susceptible to the toxin's effects (13-15). Many of these effects have been ascribed to the capacity of Ptx to modify intracellular cyclic nucleotide metabolism $(14,16)$. The A-protomer of Ptx is capable of altering the regulation of CAMP by ADP-ribosylating nucleotide-binding proteins. $\mathrm{Ni}$, a protein capable of inhibiting the activity of adenylate cyclase (17), transducin, a protein capable of enhancing the activity of cyclic GMP phosphodiesterase (18), and $\mathrm{N}_{0}$, a protein whose function and relationship to $\mathrm{Ni}$ is currently unknown $(19,20)$, have all been reported to be ribosylated by enzymatic activity of Ptx. Recent evidence also suggests that Ptx may be capable of modulating transduction systems other than adenylate cyclase (21-23). In addition, it is now appreciated that a number of the biological activities of this toxin, especially those involved in immunomodulation, are unrelated to its ADP-ribosyl transferase activity (21). Such evidence emanated from the finding that methylation or acetamidination of Ptx resulted in a loss of a number of its reported bioactivities, without modifying its ADP-ribosyl transferase activity $(24,25)$.

The objective of this study was to determine whether the mechanism(s) of action of Ptx in the murine postpertussis "encephalopathy" model recently described by Steinman et al. (26, 17) is dependent on its ability to ADP-ribosylate nucleotide binding proteins. These investigators reported that a clinical syndrome with pathological features closely resembling human postpertussis vaccination encephalopathy can be reproduced in certain strains of mice by immunization with purified preparations of Ptx and BSA (26). Our results demonstrate that the disease process invoked in mice employing this experimental model system is not a true encephalopathy. Rather, this condition represents hypovolemic shock induced by an acute hypersensitivity reaction (anaphylaxis) and not a specific neurological insult. Furthermore, the development of this immediate hypersensitivity response was established to be dependent on a class II activity of Ptx and unrelated to the capacity of toxin to alter intracellular cyclic nucleotide metabolism.

\section{MATERIALS AND METHODS}

Animals. $\mathrm{BALB} / \mathrm{cAnNCr}$ and $\mathrm{CR}: \mathrm{SW}$ mice were originally obtained from the animal production facility of the National Cancer Institute (Bethesda, MD) and bred in our colony. All mice were housed at a maximum density of six animals per $7 \times$ 
11 inch cage and maintained on Wayne sterilizable Lab Blox and acidified water ad lifitum. Mice used in experiments were $6-10$ wk of age.

('hemicals and reagents. Purified pertussis toxin was purchased from I ist Biological I aboratories ( adenine dinucleotide. guanosine triphosphate adenosine triphosphate, and thymidine from Sigma (hemical (o. (St. I.ouis. M()), borane-pyridine complex from Aldrich (hemical ( 0 .. Ine. (Milwauke, WI) formaldehyde (37\%) from J. T. Baker (hemical (o. (Phillipsburg. NJ). methyseride maleate from Sandoz Inc. (Kast Hanover. NJ), and cyproheptadine H( Irom Merek Sharp and Dohme (West Point. PA).

Methylation of Ptx: Methylated Ptx was prepared as described by Uli it al. (25). Briefly. $250 \mu \mathrm{l}$ of a stock solution of Ptx (100) $\mu \mathrm{g} / \mathrm{ml})$ in (0.) $\mathrm{M}$ phosphate buffer $(\mathrm{pH} 7 .(0) / 0.05 \mathrm{M} \vee \backslash \mathrm{Va}(\mathrm{l}$ was mixed with an equal volume of $20 \mathrm{mM}$ formaldehyde and 30 $\mathrm{mM}$ borane-pyridine complex (pI 7.0$)$ in the phosphate buffer. This reaction mixture was incubated for $2 \mathrm{~h}$ in an atmosphere of nitrogen at room temperature followed by exhaustive dialysis against phosphate-huffered saline. As a control. Ptx was treated in an identical manner with the omission of the incubation step in the presence of formaldehyde and borane-pyridine complex.

lsolation of peritomeal macrophages. Resident macrophages were obtained by lavaging the peritoneal cavity of mice with 5.0 $\mathrm{ml}$ of cold heparinized $(2 \mathrm{~J} / \mathrm{ml})$ MI:M (Flow L aboratories Inc.. Mclean, VA). (ells in the peritoneal fluid were washed and resuspended in heparin free MEM containing $10 \%$ Fes (Hy(lone Sterile System. Inc., I ogan. UT) and incubated in a glass Petri dish at $37^{\circ}$ ('within a humidified incubator $15 \%$ ( ()$\left._{2}\right)$ for 9() min. The nonadherent cells were discarded and the macrophage monolayer was collected by treatment with lidocaine.

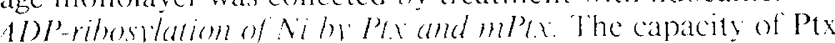
and $m P t x$ to $A I) P$-ribosylate membrane proteins was craluated using a slight modification of the procedure as described by Backlund $"$ al. (28). Briefly, murine peritoneal macrophages (5 $\times 10^{6}$ cells $/ \mathrm{ml}$ ) were suspended in MEM containing $10 \%$ FCS and either Ptx or $m P_{t x}(20) \mathrm{ng} / \mathrm{ml}$ ) for 2 h at $37^{\circ}$ ( . (rude membrane homogenates were then prepared from both the control and treated macrophages and the membrane preparations were incubated with ${ }^{3}[H] . N \wedge D$ and fresh $P t x$. The standard reaction was carricd out in $0.1 \mathrm{M}$ potassium phosphate (pH 7.0). containing $10 \mathrm{mM}$ thymidine, $1 \mathrm{mM} \wedge T \mathrm{P},($ ). $1 \mathrm{mM}$ (iTP. 1.8 $\mu \mathrm{M}^{3}[\mathrm{H}] \mathrm{N} \wedge \mathrm{D}$ (sp) act: $27.1(\mathrm{i} / \mathrm{mmol})$. activated $\mathrm{P} x(50)(\mathrm{ng})$ and cell membranes for 1 h at $37^{\circ}$ ('in a total volume of 50$) \mu$. Ptx was activated by incubation of the toxin for $30 \mathrm{~min}$ at $\mathrm{rocm}$ temperature in $50 \mathrm{mM}$ potassium phosphate buffer. pH 7.0 containing $25 \mathrm{mM}$ dithiothreitol. Membranes were washed free of unreacted $N \wedge I$ ) and the amount of incorporated radioactivity was counted with a scintillation counter (Packard Instrument (o.. Inc.. Dower (irove. I1).

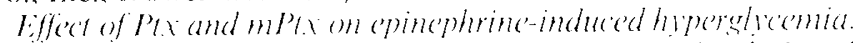
The ability of $P t x$ and $m P t x$ to inhibit epinephrine-induced hyperglycemia was evaluated using a slight modification of the method described by Yajimal ef al. (29). Briefly. the mice were given an IV injection of either Ptx or mPtx (1.30 ng). (ontrol animals were given an injection of normal saline. Seventy-two h later the mice (fasted for $(h)$ ) were subcutaneously injected with epinephrine $(200 \mu \mathrm{g} / \mathrm{kg}$ of body weight). The blood glucose concentration of each animal was determined immediately before and 60 min after the epinephrine injection. Blood specimens used for hlood glucose determinations were obtained via the retroorbital sinus. The glucose concentration of each sample was determined by the glucose oxidase method (30).

l. whphocitosis-promoling activity of Ptx and mPtx. The lymphocytosis-promoting capacity of $P t x$ and $\mathrm{mPtx}$ was assessed by quantitating the number of lymphocytes in the peripheral circulation of mice that had received an IV injection $(250 \mathrm{ng})$ of either Ptx or mPtx $72 \mathrm{~h}$ previously. Control animals received an IV infusion of normal saline. Fifty $\mu$ lof blood were obtained from each experimental and control mouse in heparinized cap- illary tuhes. Peripheral leukecye counts were determined with a hemocytometer and differential analysis of keukocytes was performed on Wrights stained blood smears. The mean values obtained from three similarly treated mice were used as an index of lymphocytosis.

Induction of the B.S.1-Ptx disedse. Mice were immunice ascording to the protocol as previously described by Steinman at al. (26). (On days -1 and +1 the mice $(B \wedge 1, B / C A n \wedge(\mathrm{C})$ were given $1 \mathrm{mg}$ of BSA in ().2 $\mathrm{ml}$ of phosphate-buffered saline IP. and on days () and 2 they were given 10() ng of Ptx or mPtx IV. On day 6 the animals were given a 1 me BSA injection and observed closely for the development of lethargy tachymea. cranosis. seizures. and death.

Adeptive transfer of B.S.1-PlX-induced disedesce. Mice (BA1.B/ c AnNCr) to be used as donors in adoptive transfer experiments were given $1 \mathrm{mg}$ of $B S A$ in $0.2 \mathrm{ml}$ of phosphate-huffered saline IP on days -1 and +1 , and 100 ng of $P t x$ or $m P t x$ by intravenous infusion on days () and 2. Peripheral blood was collected from each animal on day 6 and following sacrifice their peripheral lymph nodes were surgically excised. The peripheral hood samples were allowed to clot and then centrifuged. The serum was collected and transferred IV (0).25 ml/animal) into normal BAI B/CAn Ver mice or mice that had been injected IV with Ptx $24 \mathrm{~h}$ previously. Donor lymph nodes were gently dissociated in RPMI 1640 (Dutchland I aboratory. Inc.. Denver. P. A) supplemented with $5 \%$ FCS and the resulting single cell suspension was transferred IV (10- cells/recipient) into normal mice or mice that had received an IV infusion of $\mathrm{Ptx}$ or $\mathrm{mPtx} 24 \mathrm{~h}$ previously. (One $\mathrm{h}$ following the infusion of serum or lymphoid cells all recipients were given $1.0 \mathrm{mg}$ of $\mathrm{BSA}$ intraperitoneally. The animals were then observed closely for the next 2 h for lethargy. lachypnea. cyanosis, seimures, and death.

\section{RISLITS}

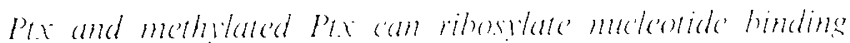
proteins. The biological activities of $P t x$ on susceptible target cells have recently been divided into two general categories. Those that are dependent on the ability of the $A$-protomer of the toxin to enter a cell and ADP-ribosylate nucleotide binding proteins such as $\mathrm{Vi}$ a $41 \mathrm{kD}$ a membrane protein insolved in cyclic nucleotide regulation. have been termed class I activitics (24). Those activities which are secondary to the hinding of the B-oligomer of Ptx to the cell surface and do not involve the modification of nucleotide binding proteins by ribosy lation have been termed class II activities (24). If "' al. (25) have previously shown that reductive methylation of $P$ tx. a procedure which results in over $90 \%$ of the amino groups of the lysine residues being dimethylated. markedly diminishes the capacity of the toxin to elicit class II activities while leaving the class I activities relatively intact.

Our first series of experiments were designed to contirm that both Ptx and mPtx were capable of ADP-ribosylating nucleotide binding proteins in wive and in vitro. As shown in lable 1. whe preincubation of intact macrophages with sither Pt. of $\mathrm{mPtx}$ resulted in an equivalent reduction of the available endogenous membrane proteins susceptible to ribosylation with activated Ptx subsequent to membrane preparation.

Ixperiments were also conducted where preparations of macrophage membranes were incubated with '[H] $\mathrm{NAD}$ ) in the presence of either Ptx or mPtx. The radiolabeled membranes then were washed and subjected to sodium dodecyl sulfate-polyary amide gel electrophoresis. Only one band of radioactivity was found. corresponding to a molecular weight of $41 \mathrm{kI}$ a scintillation counting of the isolated $41 \mathrm{kI}$ ) a band determined that the ability of $\mathrm{mPtx}$ and $\mathrm{Ptx}$ to catalye the ADP-ribosylation of the membrane protein was equivalent (data not shown). These results indicate that both Ptx and mPtx were capable of endogenously ribosvlating a $41 \mathrm{kD}$ ) a membrane protein, a class I Ptx activity. 
Table 1. ADP-ribosylation of macrophage membranes by Ptx or $m P t x$

\begin{tabular}{cc}
\hline Treatment of macrophages* & Percent of Ni ribosylated $\dagger$ \\
\hline None & 0 \\
Ptx $(20 \mathrm{ng} / \mathrm{ml})$ & $57.0 \pm 1.2$ \\
$\operatorname{mPtx}(20 \mathrm{ng} / \mathrm{ml})$ & $62.6 \pm 1.6$ \\
\hline
\end{tabular}

${ }^{*}$ Murine peritoneal macrophages were suspended at $5 \times 10^{6}$ cells per $\mathrm{ml}$ and incubated for $2 \mathrm{~h}$ at $37^{\circ} \mathrm{C}$ with either Ptx or mPtx. Crude membrane homogenates were then prepared from both the control and treated macrophages and the membrane preparations were incubated with $\left[{ }^{3} \mathrm{H}\right] \mathrm{NAD}$ and fresh Ptx. Incorporated radioactivity was then measured by scintillation counter. Maximal incorporated radioactivity ranged from 4,500-11,600 cpm for control membranes depending on the experiment.

$\dagger$ The amount of radioactivity incorporated into control membranes was considered to be $100 \%$. Results are expressed as the percentage of endogenous $\mathrm{Ni}$ no longer available for ribosylation with radiolabeled NAD. (Percentage of Ni ribosylated during initial incubation with Ptx or mPtx.) The ADP-ribosylation reactions were performed in duplicate and the experiment was repeated numerous times with equivalent results.

Ptx and mPtx block catecholamine-induced hyperglycemia. To question whether Ptx and $\mathrm{mPtx}$ could also function in vivo to mediate class I Ptx activities, experiments were designed to compare the effects of Ptx and mPtx on catecholamine-induced hyperglycemia. Katada and Ui (31) have previously demonstrated that the failure of epinephrine to induce hyperglycemia in pertussis vaccine-treated animals resulted from a paradoxical epinephrine-induced hyperinsulinemia. These investigators also presented data which established that the exaggerated insulin secretion was a consequence of the ability of Ptx to abolish the normal $\alpha$-adrenergic secretion of pancreatic cells to epinephrine (32), a class I effect.

It was determined (Table 2) that epinephrine-induced hyperglycemia could not be elicited in animals who had received either Ptx or mPtx. These findings indicate that mPtx was able to block the $\alpha$-adrenergic response of pancreatic islet cells to epinephrine to the same degree as native Ptx, a consequence previously established to be dependent upon the modification of cAMP responses in the pancreatic islet cells (33).

The methylation of Ptx attenuates the toxin's ability to mediate class II activities. We next questioned what effect methylation would have on the lymphocytosis-promoting activity of Ptx. The lymphocytosis-promoting action of Ptx has been shown to represent a class II effect of the toxin (24). As shown in Table 3, the number of lymphocytes in the peripheral circulation of animals who had been treated with native Ptx was greatly elevated over the number found in control animals. However, peripheral lymphocyte counts of animals who had received mPtx were only slightly elevated over control values. These results indicate that modification of Ptx by methylation is capable of attenuating its lymphocytosis-promoting activity and are in agreement with those previously reported by Ui et al. (25) who demonstrated that the class II biological activities of Ptx are selectively diminished following reductive methylation.

mPtx can not be substituted for Ptx in murine Ptx-BSA induced disease. Having established that $\mathrm{mPtx}$ preparation retains class I activities but has lost its class II activities, we addressed the question of whether the disease process induced by co-immunizing mice with Ptx and BSA is due to the stimulation of class I or class II activities of Ptx. BALB/cAnNCr mice were coimmunized with BSA and Ptx or BSA and mPtx as described in "Materials and methods." The results of this experiment (Table 4) confirm that animals coimmunized with Ptx and BSA become lethargic, cyanotic, tachypneic, and die within $2 \mathrm{~h}$ after receiving a challenge with BSA. In contrast, animals who had been coimmunized with methylated Ptx and BSA remained symptom free. These results suggest that the involvement of Ptx in the BSA-Ptx induced disease is not due solely to its ADP-ribosyl transferase
Table 2. Effect of Ptx and mPtx on epinephrine-induced hyperglycemia

\begin{tabular}{|c|c|c|c|c|}
\hline \multirow[b]{2}{*}{ Experiment } & \multirow[b]{2}{*}{ Group } & \multirow[b]{2}{*}{ Treatment* } & \multicolumn{2}{|c|}{$\begin{array}{l}\text { Blood glucose concentration } \\
\qquad(\mathrm{mg} / \mathrm{dl}) \dagger\end{array}$} \\
\hline & & & Before epineph & After epinephrine \\
\hline \multirow[t]{3}{*}{1} & A & None & $108 \pm 5.7 \ddagger$ & $146 \pm 16.0$ \\
\hline & B & Ptx & $84 \pm 4.1$ & $77 \pm 4.1$ \\
\hline & $\mathrm{C}$ & mPtx & $84 \pm 3.9$ & $74 \pm 2.3$ \\
\hline \multirow[t]{3}{*}{2} & A & None & $86 \pm 0.2$ & $130 \pm 0.7$ \\
\hline & B & Ptx & $82 \pm 8.3$ & $84 \pm 0.8$ \\
\hline & C & $\mathrm{mPtx}$ & $69 \pm 1.7$ & $82 \pm 0.4$ \\
\hline
\end{tabular}

* Mice received an IV injection of either Ptx or mPtx (250 ng). Control mice received normal saline.

$\dagger$ Sixty-nine $\mathrm{h}$ after the Ptx or mPtx infusion the mice (fasted for $6 \mathrm{~h}$ ) were subcutaneously injected with epinephrine $(200 \mu \mathrm{g} / \mathrm{kg}$ of body weight). The blood glucose concentration of each animal was determined immediately before and $60 \mathrm{~min}$ after receiving the epinephrine injection.

$\$$ Data are expressed as the mean \pm SEM of three similarly treated mice.

Table 3. Lymphocytosis promoting activities of Ptx and mPtx

\begin{tabular}{cclc}
\hline Experiment* & Group & Treatment $\dagger$ & $\begin{array}{c}\text { No. of lymphocytes } \ddagger \\
\left(1 \times 10^{-6} \text { cells/ml }\right)\end{array}$ \\
\hline 1 & A & None & $8.93 \pm 0.27 \S$ \\
& B & Ptx & $40.30 \pm 2.06(451 \%) \|$ \\
2 & C & mPtx & $14.30 \pm 1.90(160 \%)$ \\
& A & None & $7.82 \pm 0.84$ \\
& B & Ptx & $40.30 \pm 1.82(515 \%)$ \\
& C & mPtx & $10.60 \pm 2.32(136 \%)$ \\
\hline
\end{tabular}

${ }^{*}$ Mice utilized in the first experiment were CR:SW and those in the second were $\mathrm{BALB} / \mathrm{cAnNCr}$.

$\dagger$ Mice received an IV injection of either Ptx or mPtx (250 ng). Control mice received normal saline.

$\ddagger$ Lymphocytes were quantitated from $72 \mathrm{~h}$ postinjection peripheral blood samples.

$\S$ Data are expressed as the mean \pm SEM of three similarly treated mice.

$\|$ The number in parentheses represents the percent of control.

activity. Rather, the condition must also be associated with one of the class II or immunopotentiating activities of the toxin.

$B S A-P t x$ induced disease can be adoptively transferred to normal recipients with immune serum but not sensitized lymphoid cells obtained from BSA immunized donors. Adoptive transfer experiments were conducted to determine whether the condition caused by coimmunization with BSA and Ptx could be adoptively transferred with serum or lymphoid cells to naive or toxin-treated recipients. As shown in Table 5, under no conditions were we able to adoptively transfer the clinical disease process to normal or Ptx-treated recipients with donor lymphoid cells. Further, the results demonstrate that the pathological disorder induced by immunization with BSA and Ptx could be adoptively transferred to Ptx pretreated recipients with immune sera (group $H$, experiment 1; and group D, experiment 2). A comparison of the results obtained from this experiment indicates that the donor of the immune serum must have received Ptx in order to generate the serum factors responsible for the adoptively transferable effect. The results also establish that recipients of the immune serum must also have been pretreated with Ptx to allow the manifestation of the condition. These findings indicate that the disease induced in animals coimmunized with BSA and Ptx is dependent on the production of a humoral substance and not on the generation of a cellular immune response. The results also suggest that Ptx treatment is essential for both the afferent and efferent phases of the BSA-Ptx induced illness.

Neither the afferent nor the efferent phase of Ptx-BSA induced disease is solely dependent on the ADP-ribosyl transferase activity 
of Ptx: We next questioned whether $m P t x$ could replace $P t x$ in either of the two toxin requiring phases of the disease process (afferent or efferent). To assess the toxin's role in generating the humoral component of the response. experiments were designed in which donor mice were coimmunized with either Ptx and BSA or mPtx and BSA prior to serum collection and adoptive transfer to susceptible recipients. To evaluate the role of the toxin in the efferent phase of the process, recipient animals were "primed" with either Ptx or mPtx 24 h prior to receiving immune serum and the BSA challenge. As shown in Table 6. animals that were immunized with Ptx and BSA were capable of producing a humoral substance that, when adoptively transferred to Ptxpretreated recipients, was capable of transferring the disease process. Donor animals that were treated with $\mathrm{mPtx}$ and $\mathrm{mm-}$ munized with BSA did not generate the humoral components necessary to adoptively transfer the disorder to susceptible recipients (group $\wedge$ ). Furthermore, mPtx was also incapable of rendering normal recipients susceptible to the pathological process caused by the adoptive transfer of serum from BSA and Ptx immunized donors (group D). These results indicate that the involvement of Ptx in both the afferent and efferent phases of this process are likely associated with its class II, and not class I. biological activities.

Table 4. Murine responses to immunization with B.S.4 and Ptx or $m P t x$

Experiment (iroup Treatment* Vo. affected/no. lestedt 1 $\wedge$ B ( I) I: 2

$\begin{array}{ll}A & \text { None } \\ B & B S \wedge \\ (C & P t x \\ \text { I) } & m P t x \\ \text { E } & B S \wedge+P t x \\ \text { E } & B S \wedge+m P t x \\ A & \text { None } \\ B & B S \wedge+P t x \\ C & B S \wedge+m P t x\end{array}$

$0 / 5$

$0 / 5$

$(0 / 5$

$0 / 5$

$5 / 5 \div$

$0 / 5$

$0 / 5$

$5 / 5+$

$0 / 5$

* Mice received an IP injection of BSA (1 $\mathrm{mg}$ ) on days -1 and +1 , and an IV infusion of either Ptx or mPtx $(100$ ng) on days () and + ?

+ On day 6 all animals were challenged with an IP injection of BSA (1 mg). Animals were then observed ctosely for lethargy, tachypnea. seizure activity, and death.

\$ All animals in group 1 : (experiment 1 ) and group B (experiment 2) died within 2 h of BSA injection.
Simptoms of B.S.4-Ptx-induced diseese are amelioruted by treatment of immunized mice with serotonin antagonists and can also be reversed by fluid therapl: Since we were able to adoptively transfer the BSA-Ptx induced pathologic process with immune serum we questioned whether this process was actually due to an immediate or type I hypersensitivity response. Because the primary vasoactive amine associated with immediate hypersensitivity responses in mice is serotonin (34), we designed experiments 10 evaluate the effect of serotonin antagonists on PtX-BSAinduced disease. Mice were communized with BSA and Ptx according to the hasic protocol described in "Materials and Methods." After the challenge BSA injection on day 6. those animals that had not been pretreated with the scrotonin antagenists exhibited the typical shock-like symptoms and died within $2 \mathrm{~h}$. The animals that had been given a known serotonin antagonist seemed subjectively less active for a short period of time but otherwise remained symptom free (Table 7). These results strongly suggest that the murine BSA-Ptx-induced disorder is actually the product of an immediate-type hypersensitivity response.

Previous studies have shown that the death of mice from

Table 6. mPtx is inceffective in both afferent and efferent phesse' of B.S.1-Ptr-induced disease

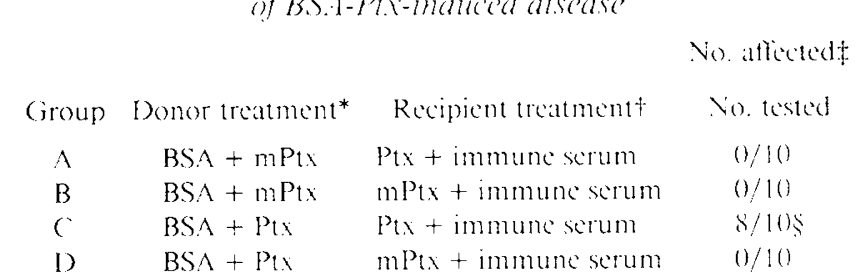

* Donor mice (BAl.B/CAn.V( r) received an IP injection of BSA on days -1 and +1 . and an IV injection of either Ptx or mPtx (f(o) ng) on days () and + ?

+ Immune serum from donor animals was prepared as described in "Materials and methods." Each recipient animal (BALB/CAn:V( $\mathrm{C}$ ) received an IV infusion of immune serum $(0.25 \mathrm{ml}) 24$ h after receiving an IV injection of either Ptx or mPtx (10) ng). (Onc hafter infusion of immune serum all recipients were given an IP) injection of BSA ( $1 \mathrm{mg})$.

† Animals were observed cfosely for tethargy tachpnea. cyanosis. scizure activity, and death.

Eight of the 10 animals became lethargic and cyanotic shortly after the IP injection of BSA. Seven of the cight died within $2 \mathrm{~h}$.

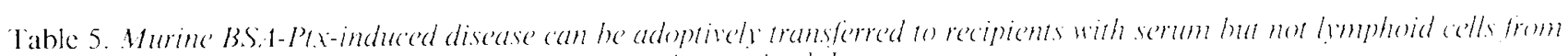
imminized donors

\begin{tabular}{|c|c|c|}
\hline lixperiment & Ciroup & Donor treatment* \\
\hline \multirow[t]{8}{*}{1} & A & BSA \\
\hline & B & $B S A$ \\
\hline & (c & $P \operatorname{tx}$ \\
\hline & D) & $P t x$ \\
\hline & ミ: & $B S A+P t x$ \\
\hline & I: & $\mathrm{BSA}+\mathrm{Ptx}$ \\
\hline & (j) & $\mathrm{BSA}+\mathrm{Ptx}$ \\
\hline & H & $B S A+P 1 x$ \\
\hline \multirow[t]{4}{*}{2} & $\wedge$ & $\mathrm{BSA}+\mathrm{Ptx}$ \\
\hline & B & $B S A+P 1 x$ \\
\hline & (c) & $\mathrm{BSA}+\mathrm{Ptx}$ \\
\hline & I) & $B S A+P t x$ \\
\hline
\end{tabular}

$\quad$ Recipient deament
Ptx + immune lymphocytes
Ptx + immune serum
Ptx + immune lymphocytes
Ptx + immune serum
Immune lymphocytes
Ptx + immune lymphocytes
Immune serum
Ptx + immune serum
Immune lymphocytes
Ptx + immune lymphocytes
Immune serum
Ptx + immune serum

No. afrectedt

Vo. lested

$0 / 5$
$0 / 5$
$0 / 5$
$0 / 5$
$0 / 5$
$0 / 5$
$0 / 5$
$5 / 58$
$0 / 5$
$0 / 5$
$0 / 5$
$5 / 53$

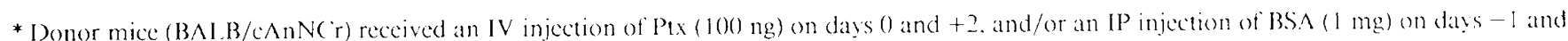
+1 . On day 6 peripheral blood was collected from each animal. they were then sacrificed and their peripheral lymph nodes excised.

+ I.ymphoid cells and immune serum were prepared from donor animals as described in "Material and methods." Fach recipient animal received an IV infusion of $1 \times 10^{7} \mathrm{lymph}$ node cells or $0.25 \mathrm{ml}$ of immune serum. Selected groups of recipients had received an IV injection of $P$ tx $24 \mathrm{~h}$ prior to adoptive transfer. An IP injection of BSA was given to all recipients $1 \mathrm{~h}$ after receiving the infusion of immune serum or lymphoid cells.

I Animals were observed closely for lethargy, tachypnea, cyanosis, scizure activity, and death.

$\$$ All recipient animals in groups $\mathrm{H}$ (experiment 1$)$ and $\mathrm{D}$ (experiment 2 ) died within $2 \mathrm{~h}$ of receiving the IP injection of BSA. 
Table 7. Effect of serotonin antagonists on development of BSAPtx-induced disease

\begin{tabular}{|c|c|c|}
\hline & & No. of deathst \\
\hline Group* & Treatment $\dagger$ & No. tested \\
\hline A & None & $6 / 6$ \\
\hline B & Cyproheptadine & $0 / 6$ \\
\hline $\mathrm{C}$ & Methyseride & $0 / 6$ \\
\hline D & IV normal saline§ & $0 / 6 \|$ \\
\hline
\end{tabular}

* All mice (BALB/cAnNCr) were coimmunized with BSA and Ptx according to the protocol listed in "Material and methods."

† The animals in group B were given $0.6 \mathrm{mg}$ of Cyproheptidine by gavage every $6 \mathrm{~h}$ beginning on day 4 of the protocol. Group $C$ received $2.5 \mathrm{mg}$ of Methsergide every $6 \mathrm{~h}$. The animals in group A were gavaged with normal saline. On day 6 all animals were given an IP injection of BSA (1 mg)

¥Animals were observed closely for lethargy, tachypnea, cyanosis, seizure activity, and death.

$\S$ Animals were given $0.5 \mathrm{ml}$ of normal saline intravenously within 10 min of becoming symptomatic (all animals in group D demonstrated lethargy, tachypnea, and mild cyanosis within $30 \mathrm{~min}$ of IP BSA injection)

\| All animals in group A died within $2 \mathrm{~h}$ of BSA challenge.

immediate hypersensitivity reactions is due to loss of blood volume (35). With this knowledge we questioned whether volume expansion of the animals during the acute stages of their illnesses would clinically modify the disease process. One group of Ptx and BSA immunized animals was therefore given an intravenous infusion of normal saline $(0.5 \mathrm{ml})$ within 10 min of becoming symptomatic. We found that the animals that received a bolus of normal saline shortly after becoming symptomatic survived (group D), while those that did not receive fluid therapy died (group A). These results lend support to the hypothesis that the clinical condition produced by coimmunizing mice with Ptx and BSA is secondary to an immediate type hypersensitivity response (anaphylaxis) and does not resemble or simulate the neurological illness temporally related to pertussis immunization in infants.

\section{DISCUSSION}

Steinman et al. (26) recently reported that a clinical syndrome with pathological features very similar to postpertussis vaccination encephalopathy could be induced in specific strains of mice after their immunization with BSA and Ptx. Previously, this same group established that a similar type of clinical condition could be induced in mice by immunization with BSA and pertussis vaccine (27) and suggested the possibility of an anaphylactic-type reaction being responsible. The original intention of the present investigation was to determine whether the mechanism of action of Ptx in this murine model was related to the toxin's capacity to induce a class I or class II activity. Our studies, however, have now established that Steinman's model is not one of neurologic encephalopathy but rather is the result of vascular collapse secondary to an anaphylactic reaction. Several lines of experimental evidence support this conclusion: 1) sensitivity to the BSA-Ptx-induced disease can be passively transferred with the immune serum obtained from sensitized animals into Ptxtreated recipients; 2) animals that are immunized with BSA and Ptx and then pretreated with serotonin antagonists prior to BSA challenge do not develop the typical clinical manifestations of the disorder; and 3) symptoms of the condition can possibly be alleviated by giving BSA-Ptx immunized animals fluid therapy as soon as clinical manifestations are noted following the BSA challenge.

In mice, both $\operatorname{IgG}_{1}$ and $\operatorname{IgE}$ can function to induce antigenspecific release of mediators from mast cells and basophils that are capable of initiating immediate type hypersensitivity reactions (36). Antibodies belonging to the $\mathrm{IgG}_{1}$ subclass, unlike IgE, are not inactivated by heating at $56^{\circ} \mathrm{C}$ or by sulfhydryl reagents (37). We have determined that heating the serum from BSA-Ptx sensitized animals for $30 \mathrm{~min}$ at $56^{\circ} \mathrm{C}$ did not diminish the ability of that immune serum to passively transfer anaphylactic sensitivity to Ptx primed recipients (data not shown). These results suggest, but do not prove, that antibodies of the $\operatorname{IgG}_{1}$ subclass may be involved in the BSA-Ptx-induced immediate hypersensitivity reaction. Further work is in progress to test this hypothesis.

Our studies have also revealed that the development of anaphylaxis in this murine system exhibits some interesting characteristics. By employing preparations of Ptx and mPtx in parallel we were able to demonstrate that the ADP-ribosyl transferase capacity of pertussis toxin is insufficient to initiate the BSA-Ptxinduced immediate type hypersensitivity reaction. Our findings also indicate that the development of this reaction is associated with a class II or immunopotentiating activity of the toxin. In a series of adoptive transfer experiments we further demonstrated that both the donor of the humoral component and the recipients of the immune serum need to be treated with Ptx for the BSAPtx induced hypersensitivity response to take place. mPtx could not substitute for Ptx in either the afferent or efferent phase of this process.

While the murine model system described Steinman et al. (26) originally looked quite promising, our finding that the experimentally produced condition actually represents an immediatetype hypersensitivity reaction rather than a true encephalopathy indicates that an experimental model for human postpertussis vaccination encephalopathy is still lacking.

\section{REFERENCES}

1. Kulenkampff M, Schwartzman JS, Wilson J 1974 Neurological complications of pertussis inoculation. Arch Dis Child 49:46-49

2. Madsen T 1933 Vaccination against whooping cough. JAMA 101:187-188

3. Prensky AL 1974 Pertussis vaccination. Dev Med Child Neurol 16:539-543

4. Cody CL, Baraff LJ, Cherry JD, March SM, Manclark CR 1981 Nature and rates of adverse reactions associated with DTP and DT immunizations in infants and children. Pediatrics 68:650-660

5. Strom J 1967 Further experience of reactions, especially of a cerebral nature, in conjunction with triple vaccination: a study based on vaccinations in Sweden 1959-65. Br Med J 4:320-323

6. Byers RK, Moll FC 1948 Encephalopathies following prophylactic pertussis vaccinc. Pediatrics 1:437-4547

7. Sutherland JM 1953 Encephalopathy following diptheria-pertussis inoculation. Arch Dis Child 28:149-150

8. Thursby-Pelham DC, Viles C 1958 Neurologic complications of pertussis immunization. Br Med J 2:246

9. Pittman M 1979 Pertussis toxin: the cause of the harmful effects and prolonged immunity of whooping cough. A hypothesis. Rev Infect Dis 1:401-41

10. Pittman M 1984 The concept of pertussis as a toxin-mediated disease. Pediatr Infect Dis 3:467-486

11. Tamura M, Nogimori K, Murai S, Yajima M, Ito K, Katada T, Ui M 1982 Subunit structure of Islet-activating protein, pertussis toxin, in conformity with the A-B model. Biochemistry 21:5516-5522

12. Munoz JJ, Arai H, Bergman RK, Sadowki PL 1981 Biological activities of crystalline pertussigen from Bordetella pertussis. Inf Immun 33:820-826

13. Katada T, Ui M 1980 Slow interaction of islet-activating protein with pancreatic islets during primary culture to cause reversal of $\alpha$-adrenergic inhibition of insulin secretion. J Biol Chem 255:9580-9588

14. Hazeki O, Ui M 1981 Modification by islet-activating protein of receptormediated regulation of cyclic AMP accumulation in isolated rat heart cells. J Biol Chem 256:2856-2862

15. Parker CW, Morse SI 1973 The effect of Bordetella pertussis in lymphocyte cyclic AMP metabolism. J Exp Med 137:1078-1090

16. Katada T, Ui M 1982 Direct modification of the membrane adenylate cyclase system by islet-activating protein due to ADP-ribosylation of a membrane protein. Proc Natl Acad Sci USA 79:3129-3133

17. Katada T, Tamura M, Ui M 1983 The A-protomer of islet-activating protein, pertussis toxin, as an active peptide catalyzing ADP-ribosylation of a membrane protein. Arch Biochem Biophys 224:290-298

18. Van Dop C, Yamanaka G, Steinberg F, Sekura RD, Manclark CR, Stryer L, Bourne HR 1984 ADP-ribosylation of transducin by pertussis toxin blocks the light stimulated hydrolysis of GTP and CGMP in retinal photoreceptors. J Biol Chem 259:23-36

19. Sternweis PC, Robishaw JD 1984 Isolation of two proteins with high affinity for guanine nucleotides from membranes of bovine brain. $J$ Biol Chem 259:13806-13813

20. Neer EJ, Lok JM, Wolf LG 1984 Purification and properties of the inhibitory guanine nucleotide regulatory unit of brain adenylate cyclase. J Biol Chem 
$259 \cdot 14222-14229$

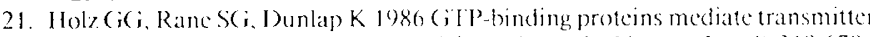
inhibition of voltage-dependent calcium channels. Nature (Lond) 319:670)672

22. Burch RM, I uini A. Axclrod J 1986 Phospholipase $A$ and phospholipase ( are activated by distinct ( $i l P^{2}$-binding proteins in response to $x_{1}$-atrenergic stimulation in IRTIS thyroid cells. Proc Vatl Sci USA 8.3:7201-7205

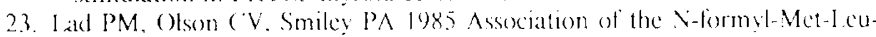
Phe receptor in human neutroptils with a (iTP-binding protein sensitive w perlussis loxin. Proc Natt Acad Sci l ISA 82:869-87.3

24. Nogimori K. Tamura M. Yaijma M. Ito K. Vakamura I. Kajikawa $\mathcal{X}$ Maruyama Y. Li M 1984 Dual mechanisms involved in the development of diverse biological activities of islet-actiadting protein, pertussis toxin. as revealed by chemical modification of Ivsine residues in the toxin molecule. Biochim Bionteys Acta 80)1.232-243

25. Ui M Nogimori $K$. Tamura M 1985 Isketactivating protein. pertussis toxin subunit structure and mechanism for its multiple biological actions. In Sckura RI). Moss I. Vatighen M (eds) Pertussis Ioxin. Academic Press. Vew York, p] 19-4.3

26. Stcimm ralkow $S 1985$ pertussis toxin is reguired for pertussis vaccine encephalopathy. Pro Natl Acad Soj USA 82:87.3.3-87.36

27. Steinman 1. Sriram S. Adelman NI, Zamvil S. Med devitt HO. Utrich 1198 ? Murine model for pertussis vaccine encephalopathy: linkage to H-2. Vature $299: 73 \times-740$

28. Backlund PS. Mead BI). Manclark ( R. (antoni (il. Aksamii RR 1985 Pertussis toxin inhibition of chemotaxis and the ADP-ribosylation of a membranc protein in a human-mouse hobrid ecll line Proc Varl taad So IISA $\times 2: 26,37-26+1$

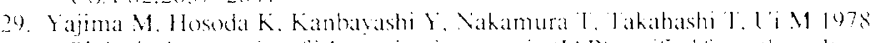
Biological properties of islet-actisating protein (IAP) puritied from the culture

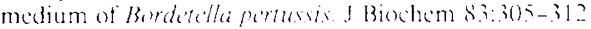

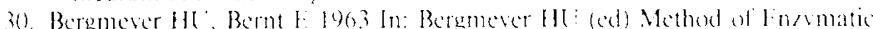
Analysis Academic Press New Jork. po 123-124

31. Katada T. Li 19 1976 Acolerated tumoser of hlood glucose in pertussis sensitired rats due to combined actions of endegenous insulin and adtenergie Beta-stimulation. Biochim Biophs leta $4.2157 \ldots 06$

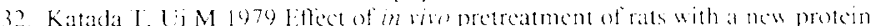


calcium. Fondocrinology $104: 1822-1827$

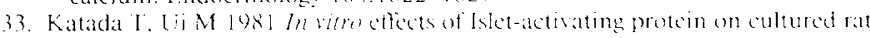

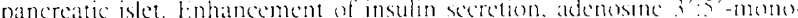

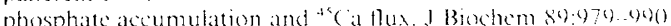

34. (iriswold J)I). (aveki 1:M 1971 ()uantitation of immediate hypersenstivis in various mouse strains. Int arch Allorgy $40: 6,82 \ldots(190)$

35. Munoz JJ. Bergman RK 1977 Bordetella permesis. Immunologgcal and other biological activities. In: Rose $\searrow$ (ed) Immumolone Series vol it. Marce Dekker Ine liow rork

36. Stechschulte [D J 1978 Von-lgy: homocytotrophic antibodics in animals. In Bach MK (ed) Immediate Hypersensitwity-Medern (encepts and I) Delogments. Mareel Dekker lnc.. Vew York. pp 259.276

37 Dorrington $k$ 1. Bennich 11 1973 Thermally induced structural changes in immunoglobulin 1: J Biol (hem 248:8378-8.3ist 